\title{
Immune Responses and Egg Productions of Quails Fed Rations Supplemented with Larvae Meal of Black Soldier Fly (Hermetia illucens)
}

\author{
Harlystiarini $^{a}$, R. Mutia ${ }^{a}$, I. W. T. Wibawan ${ }^{b}$, \& D. A. Astuti ${ }^{a}, *$ \\ aDepartment of Nutrition and Feed Technology, Faculty of Animal Science, IPB University \\ (Bogor Agricultural University) \\ ${ }^{b}$ Faculty of Veterinary Medicine, IPB University (Bogor Agricultural University) \\ Jalan Agatis, Kampus IPB Darmaga, Bogor 16680, Indonesia \\ *Corresponding author: dewiapriastuti86@gmail.com \\ (Received 06-09-2018; Revised 07-08-2019; Accepted 26-08-2019)
}

\begin{abstract}
The larvae of black soldier fly/BSF (Hermetia illucens) seems to be a considerable material as an alternative to antibiotic growth promoters (AGPs) since they are rich in antimicrobial peptides (AMPs) and lauric acid that can improve the health and immune response. This study aimed to evaluate the effect of BSF larvae meal as a replacement of fish meal on production performances, health status, and immune response of quails. The experimental design using completely randomized design consisted of 3 treatments of dose of BSF larvae meal i.e., R0: ration without supplementation of BSF larvae meal; R1: ration supplemented with $6.57 \%$ BSF larvae meal to substitute $50 \%$ fish meal, and R2: ration supplemented with $13.15 \%$ BSF larvae meal to substitute $100 \%$ fish meal. The parameters observed were production performances, hematological profile, macrophage phagocytic activity and capacity, and antibody titer against the avian influenza virus. A completely randomized design was arranged with 3 treatments and 5 replications and data collected were analyzed by using one-way analysis of variance (ANOVA). The results showed that ration supplemented with $13.15 \%$ BSF larvae meal demonstrated significant effects on the enhancement of egg production and egg mass $(\mathrm{p}<0.05)$. Based on hematological profile, the health status of experimental quails was unaltered by the treatments, but immune response of quails fed ration supplemented with $13.15 \%$ BSF larvae meal was found to be significantly increased as revealed by the increased average macrophage phagocytic activity and capacity, as well as a higher antibody titer against avian influenza virus $(\mathrm{p}<0.05)$. It is concluded that black soldier fly (BSF) larvae meal can be used as an alternative substitution to fish meal up to $13.15 \%$, based on the improvement of immune response and the increase in egg production of quails.
\end{abstract}

Keywords: black soldier fly; chitin; egg production; immunity; quail

\section{INTRODUCTION}

The consumption of animal products has been on a continuous increase over the world; thus, there is a need to increase the production of livestock. Food and Agricultural Organization (FAO) reported that animal products should be increased by $60 \%-70 \%$ to fulfill the demand for the worldwide population in 2050 (Makkar et al. 2014). However, to date, the industry is still facing many challenges, such as the limited sources of feed ingredients, the ban of using antibiotic growth promoters (AGPs), diseases, environmental, and climate changes. An insect is one of the alternative feed materials to fulfill the protein deficiency problem (Van Huis et al., 2014) in the animal industry.

For years, AGPs were always used in animal rations in sub-therapeutic concentrations to maintain gastrointestinal (GIT) health, produce a better feed conversion, and maximum production performance. The use of AGPs was banned due to the residual effects of the antibiotics that may trigger the adverse impact on either animals or consumers of animal products. Therefore, in the last few years, the study on searching the alternative preparations to replace AGPs has been extensively conducted (Steiner \& Syed, 2015).

The black soldier fly (BSF) is a fly (Diptera) that belongs to Stratiomyidae family and exists in the tropic and sub-tropic areas $\left(46^{\circ} \mathrm{NL}-42^{\circ} \mathrm{SL}\right)$ (Martínez-Sánchez et al., 2011). The life cycle of BSF takes about 38-41 days and consists of five life stages, i.e., egg, larva, prepupa, pupa, and adult (Oliveira et al., 2015). The BSF larvae harvested at the age of 14 days contain $42.1 \%$ crude protein, 34.8\% fat, and 7\% crude fiber (Newton et al. 2005, Park 2016). Meanwhile, the essential amino acid profile of BSF larvae meal contains $0.9 \%$ methionine, $3.4 \%$ lysine, $3.5 \%$ leucine, $2.0 \%$ isoleucine, $1.9 \%$ histidine, $2.2 \%$ alanine, $2.2 \%$ arginine, and $3.4 \%$ valine (Jayanegara et al., 2017).

Previous researches reported that the antimicrobial activity of hemolymph or maggot/larvae extract (Choi et al., 2012). The BSF larvae could serve as a scavenger and exist in extreme environments such as manure, compost, and other organic wastes in which bacteria and fungi could develop very well. Concerning these 
biological characteristics, the BSF larvae have antimicrobial peptides (AMPs) (Park et al. 2014). Besides, the BSF larvae also contain a high amount of lauric acid, a fatty acid that is widely recognized as a natural antimicrobial agent (Kim \& Rhee, 2016). Moreover, BSF larvae contain a small amount of chitin on their exoskeleton structures. Bovera et al. (2015) reported that chitin is a polysaccharide that in a short amount can improve the immune response.

To date, the use of BSF larvae meal is rarely studied in poultry ration (Maurer et al., 2015). Therefore, this study aims to evaluate the production performances, health status, and immune response of quails fed ration containing BSF larvae meal as a novel protein source to substitute fish meal as a conventional protein source.

\section{MATERIALS AND METHODS}

\section{Preparation of Black Soldier Fly (BSF) Larvae Meal}

The BSF larvae were obtained from Balai Riset Budidaya Ikan Hias, Depok, West Java. The larvae were fed with kitchen waste, harvested at 15 days old, and were kept in the freezer. To make the larvae meal, the frozen larvae were thawed and steamed for 45 minutes at $\pm 90^{\circ} \mathrm{C}$ to reduce the fat content. The steamed larvae were dried at $60^{\circ} \mathrm{C}$ for 24-48 hours and finely ground. The nutrient and amino acid contents of BSF larvae meal compared to those of fish meal are presented in Table 1. The ration was formulated based on the compositions of nutrients and amino acid content according to Leeson

Table 1. Nutritional and amino acid contents of black soldier fly (BSF) larvae meal compared to fish meal

\begin{tabular}{lcc}
\hline Nutrients and amino acid & $\begin{array}{c}\text { Black soldier fly } \\
\text { larvae meal }\end{array}$ & $\begin{array}{c}\text { Fish } \\
\text { meal }^{2}\end{array}$ \\
\hline Dry matter (\%) & 95.64 & 92.50 \\
Crude protein (\%) & 36.60 & 48.40 \\
Crude fiber (\%) & 7.00 & 1.30 \\
Ether extract (\%) & 27.36 & 2.00 \\
Ash (\%) & 12.17 & 35.20 \\
Gross energy (kcal kg-1) & 5610 & - \\
Metabolizable energy (kcal kg-1) & - & 2750 \\
Calcium (\%) & 3.85 & 6.50 \\
Phosphorus (\%) & 0.94 & 4.00 \\
Sodium (\%) & 0.36 & 1.02 \\
Histidine (\%) & 0.83 & 1.16 \\
Threonine (\%) & 1.40 & 1.94 \\
Arginine (\%) & 2.26 & 2.52 \\
Tyrosine (\%) & 2.83 & 1.55 \\
Methionine (\%) & 0.78 & 1.26 \\
Valine (\%) & 2.76 & 2.52 \\
Phenylalanine (\%) & 2.02 & 1.94 \\
Isoleucine (\%) & 2.17 & 1.98 \\
Leucine (\%) & 2.95 & 3.63 \\
Lysine (\%) & 2.37 & 3.39 \\
\hline
\end{tabular}

Note: 1) Analyzed by Lab. Pusat Penelitian Sumberdaya Hayati dan Bioteknologi, IPB and Lab. Ilmu dan Teknologi Pakan, IPB (2016); 2) Heuźe et al. (2015); 3) Analyzed by Lab. Terpadu IPB (2016), the content was calculated according to the total amino acid.
\& Summers (2005). The ration contained $18 \%$ crude protein and $2950 \mathrm{kcal} / \mathrm{kg}$ metabolizable energy (Table 2 and Table 3).

\section{Dietary Treatment and Feeding Duration}

The dietary treatment was applied to 150 laying quails (4 weeks old). The feeding trials consisted of 3 treatments, i.e. ration without BSF larva meal supplementation (R0), ration supplemented with $6.57 \%$ BSF larva meal to substitute $50 \%$ fish meal (R1), ration supplemented with $13.15 \%$ BSF larva meal to substitute $100 \%$ fish meal (R2).

The quails were reared for seven weeks (one week for adaptation and six weeks for feeding trial). Feed and water were provided ad libitum. Feed consumptions were measured weekly, while egg production and egg weight were recorded every day during the treatment.

Table 2. Composition and nutritional contents of experimental rations

\begin{tabular}{lrrr}
\hline \multirow{2}{*}{ Feed ingredients } & \multicolumn{3}{c}{ Treatments (\%) } \\
\cline { 2 - 4 } & \multicolumn{1}{c}{ R0 } & \multicolumn{1}{c}{ R1 } & \multicolumn{1}{c}{ R2 } \\
\hline Maize & 60.00 & 51.90 & 43.00 \\
Rice bran & 0.00 & 9.34 & 17.53 \\
Soybean meal & 18.50 & 17.50 & 16.00 \\
Fish meal & 10.00 & 5.00 & 0.00 \\
BSF larvae meal & 0.00 & 6.57 & 13.15 \\
Dicalcium phosphate & 0.00 & 0.00 & 0.45 \\
Crude palm oil & 3.20 & 2.20 & 2.38 \\
CaCO3 & 7.47 & 6.60 & 6.50 \\
Sodium & 0.23 & 0.23 & 0.22 \\
Premix & 0.50 & 0.50 & 0.50 \\
L-Lysine & 0.02 & 0.00 & 0.00 \\
DL-Methionine & 0.08 & 0.16 & 0.27 \\
Total & 100.00 & 100.00 & 100.00 \\
\hline
\end{tabular}

Note: $\mathrm{BSF}=$ black soldier fly, $\mathrm{R} 0=$ ration without supplementation of $\mathrm{BSF}$ larvae meal; R1= ration supplemented with $6.57 \%$ BSF larvae meal to substitute $50 \%$ fish meal, and R2= ration supplemented with $13.15 \%$ BSF larvae meal to substitute $100 \%$ fish meal.

Table 3. Nutritional contents of experimental rations

\begin{tabular}{lccc}
\hline \multirow{2}{*}{ Nutrients contents } & \multicolumn{3}{c}{ Treatments } \\
\cline { 2 - 4 } & \multicolumn{1}{c}{ R0 } & R1 & R2 \\
\hline Dry matter (\%) & 87.68 & 87.16 & 87.37 \\
Ash (\%) & 11.23 & 11.10 & 11.52 \\
Crude protein (\%) & 17.11 & 17.45 & 17.87 \\
Ether extract (\%) & 5.54 & 5.87 & 8.56 \\
Crude fiber (\%) & 2.38 & 2.71 & 3.54 \\
Gross energy (kcal kg-1) & 3671 & 3551 & 3720 \\
Metabolizable energy & 2982.8 & 2952.1 & 2955.4
\end{tabular}

$\left(\mathrm{kcal} \mathrm{kg}^{-1}\right)^{2)}$

Note: $\mathrm{BSF}=$ black soldier fly, $\mathrm{R} 0=$ ration without supplementation of BSF larvae meal; R1= ration supplemented with $6.57 \%$ BSF larvae meal to substitute $50 \%$ fish meal, and R2= ration supplemented with $13.15 \%$ BSF larvae meal to substitute $100 \%$ fish meal.

1) Analyzed at the Lab. Pusat Penelitian Sumberdaya Hayati dan Bioteknologi, IPB and Lab. Ilmu dan Teknologi Pakan, IPB (2017); 2) Calculated value (Leeson \& Summers, 2005). 
The blood sample $(2 \mathrm{~mL})$ was drawn from the jugular vein using a syringe in the morning on the last day of treatment. About $1 \mathrm{~mL}$ of the blood sample was put into the tube containing an anticoagulant (Ethylenediaminetetraacetic acid or EDTA) for the evaluation of hematological profile. For the measurement of antibody titer, $1 \mathrm{~mL}$ of the blood sample was put in the tube (without anticoagulant) to obtain serum.

The evaluation of the peritoneum macrophage phagocytic activity and capacity was performed at the end of the study using 15 quails from 3 treatment groups with 5 replications. The experimental quail were injected intraperitoneally with $1 \mathrm{~mL}$ of Staphyllococcus aureus non-protein A containing $10^{5} \mathrm{CFU}$ bacterial counts. The injected quails were allowed to respond to the infection for 4 hours. At the end of infection, the quail was euthanized and the peritoneal cavity was opened to take the peritoneum fluid using $1 \mathrm{~mL}$ syringe. The peritoneal fluid was put in the Eppendorf tube and was kept in cold containers until use. For the evaluation of phagocytic activity and capacity, the peritoneum fluid was prepared and stained with Giemsa solution, and the slide was observed under a microscope. The phagocytic activity was estimated as a percentage of active macrophage cells taking part in the phagocytosis (from a total of 50 macrophage cells). Meanwhile, the phagocytic capacity was estimated as a percentage of engulfed bacterial counts by 50 macrophage cells. The antibody titer against the avian influenza virus was measured using the Hemagglutination Inhibition test (OIE 2015).

\section{Experimental Design, Parameter, and Statistical Analysis}

A completely randomized design was arranged with 3 treatments and 5 replications (ten quails of each replication), and the experimental quails were reared in 15 cages $(60 \times 40 \times 20 \mathrm{~cm})$. The collected data were analyzed by using one-way analysis of variance (ANOVA) with SPSS 20.0. The significance of their differences was verified using Duncan's multiple range test.

\section{RESULTS}

\section{Hematological Profile}

The substitution of fish meal with BSF larvae meal did not demonstrate a significant effect on hematologi- cal profiles of quails (Table 4). The averages of erythrocyte number, hematocrit percentages, hemoglobin percentage, mean corpuscular volume (MCV), and mean corpuscular hemoglobin concentration (MCHC) are presented in Table 6. However, the BSF larvae meal supplementation showed a significant decrease in leucocyte number $(p<0.05)$, and the control quails without BSF larvae meal supplementation (R0) showed the highest number of leucocyte compared to the quails fed ration supplemented with $6.57 \%$ (R1) and $13.15 \%$ (R2) BSF larvae meal (Table 5). The experimental quails fed ration supplemented with $6.57 \%$ and $13.15 \%$ BSF larvae meals had a similar number of leucocytes. However, the profiles of differential leucocyte (lymphocyte, heterophils, and monocyte), as well as the ratio of heterophils to lymphocyte (H/L ration), were similar in all treatments.

\section{Macrophage Phagocytic Activity and Capacity}

The results showed that BSF larvae meal supplementation significantly increased the phagocytic activity and capacity of macrophage $(\mathrm{p}<0.05)$ (Table 6). The phagocytic activity and capacity of macrophage increased along with the increased level of BSF larva meal supplementation in the ration. The quails fed ration supplemented with BSF larvae meal at the level of $13.15 \%$ had the highest phagocytic activities and capacities $(\mathrm{p}<0.05)$ compared to those fed rations supplemented with BSF larvae meal at the levels of $0 \%$ and $6.57 \%$. Besides, quails fed ration supplemented with BSF larvae meal at the level of $6.5 \%$ had higher phagocytic activities and capacities compared to control quails fed ration without BSF larvae meal supplementation.

\section{Antibody Titer}

The incorporation of BSF larvae meal in the diet significantly increased the titer of antibodies against avian influenza (AI) virus in quails (Table 6). Quails fed ration supplemented with BSF larvae meal at the level of $13.15 \%$ (R2) demonstrated the highest titer of antibody against AI virus compared to the other groups. However, quails fed ration supplemented with BSF larvae meal at the level of $13.15 \%$ (R2) had similar ( $p>0.05)$ titer of antibody against AI virus compared to quails fed ration supplemented with BSF larvae meal at the level of $6.57 \%$ (R1). Also, quails fed ration supplemented with BSF larvae meal at the level of $6.57 \%$ (R1) had similar

Table 4. The average of erythrocyte and erythrocyte index of quails fed ration supplemented with different levels of black soldier fly (BSF) larvae meal during 6 weeks of treatment

\begin{tabular}{|c|c|c|c|c|}
\hline \multirow{2}{*}{ Variables } & \multicolumn{3}{|c|}{ Treatments } & \multirow{2}{*}{ Standard ${ }^{*}$} \\
\hline & R0 & R1 & $\mathrm{R} 2$ & \\
\hline Erythrocyte $\left(10^{6} \mathrm{~mm}^{-3}\right)$ & $3.56 \pm 0.83$ & $3.22 \pm 0.32$ & $3.51 \pm 0.67$ & $4.0-5.2$ \\
\hline Hematocrit (\%) & $37.40 \pm 6.32$ & $35.40 \pm 1.52$ & $40.00 \pm 6.79$ & $30.0-45.1$ \\
\hline Hemoglobin (g \%) & $10.58 \pm 2.82$ & $10.14 \pm 1.51$ & $10.12 \pm 1.57$ & $10.7-14.3$ \\
\hline $\operatorname{MCV}(\mathrm{fl})$ & $110.60 \pm 34.61$ & $110.79 \pm 12.45$ & $118.23 \pm 33.08$ & $60-100$ \\
\hline $\mathrm{MCHC}(\%)$ & $28.05 \pm 3.62$ & $28.77 \pm 5.16$ & $25.88 \pm 6.13$ & $28-38.5$ \\
\hline
\end{tabular}

Note: R0= ration without supplementation of BSF larva meal; R1= ration supplemented with $6.57 \%$ BSF larva meal to substitute $50 \%$ fish meal; R2= ration supplemented with $13.15 \%$ BSF larva meal to substitute $100 \%$ fish meal; ${ }^{*}$ According to Campbell (2015); MCV= Mean corpuscular volume; $\mathrm{MCHC}=$ Mean corpuscular hemoglobin concentration 
Table 5. The averages of leucocyte, differential leucocyte, and ratio $\mathrm{H} / \mathrm{L}$ of quails fed ration supplemented with different levels of black soldier fly (BSF) larvae meal during 6 weeks of treatment

\begin{tabular}{|c|c|c|c|c|}
\hline \multirow{2}{*}{ Variables } & \multicolumn{3}{|c|}{ Treatments } & \multirow{2}{*}{ Standard ${ }^{*}$} \\
\hline & R0 & R1 & R2 & \\
\hline Leucocyte $\left(10^{3} \mathrm{~mm}^{-3}\right)$ & $1.89 \pm 2.10^{\mathrm{a}}$ & $1.47 \pm 2.05^{\mathrm{b}}$ & $1.30 \pm 2.08^{b}$ & $1.3-2.5$ \\
\hline Lymphocyte (\%) & $72.40 \pm 2.61$ & $70.20 \pm 2.17$ & $69.00 \pm 4.36$ & $50-70$ \\
\hline Lymphocyte $\left(10^{3} \mathrm{~mm}^{-3}\right)$ & $1.37 \pm 0.16$ & $1.04 \pm 0.16$ & $0.90 \pm 0.19$ & $0.65-1.75$ \\
\hline Heterophils (\%) & $25.80 \pm 3.11$ & $29.00 \pm 2.65$ & $30.00 \pm 4.30$ & $25-50$ \\
\hline Heterophils $\left(10^{3} \mathrm{~mm}^{-3}\right)$ & $0.49 \pm 0.07$ & $0.43 \pm 0.06$ & $0.39 \pm 0.05$ & $0.38-1.3$ \\
\hline Monocyte (\%) & $1.80 \pm 0.84$ & $0.80 \pm 0.84$ & $1.00 \pm 0.71$ & $0-4$ \\
\hline Monocyte $\left(10^{3} \mathrm{~mm}^{-3}\right)$ & $0.04 \pm 0.02$ & $0.01 \pm 0.01$ & $0.01 \pm 0.01$ & $0-0.1$ \\
\hline $\mathrm{H} / \mathrm{L}$ ratio & $0.36 \pm 0.06$ & $0.41 \pm 0.05$ & $0.44 \pm 0.09$ & $0.3-0.5$ \\
\hline
\end{tabular}

Note: R0= ration without supplementation of BSF larva meal; R1= ration supplemented with $6.57 \%$ BSF larva meal to substitute $50 \%$ fish meal; R2= ration supplemented with $13.15 \%$ BSF larva meal to substitute 100\% fish meal; *According to Campbell (2015); H/L: heterophils-lymphocyte ratio; Means in the same row with different superscripts differ significantly $(p<0.05)$.

Table 6. The average of macrophage phagocytic activity and capacity against $S$. aureus non-protein A and antibody titer against avian influenza virus in quails fed ration supplemented with different levels of black soldier fly (BSF) larvae during 6 weeks of treatment

\begin{tabular}{|c|c|c|c|c|c|}
\hline \multirow{2}{*}{ Variables } & \multicolumn{5}{|c|}{ Treatments } \\
\hline & R0 & $\mathrm{R}$ & & R2 & \\
\hline $\begin{array}{l}\text { Macrophage phagocytic } \\
\text { activity (\%) }\end{array}$ & $60.17 \pm 7.91^{c}$ & $77.00 \pm$ & $4.34^{\mathrm{b}}$ & $89.83 \pm$ & 3.32 \\
\hline $\begin{array}{l}\text { Macrophage phago- } \\
\text { cytic capacity (per cell } \\
\text { macrophage) }\end{array}$ & $2.18 \pm 0.66^{c}$ & $5.42 \pm$ & $1.39^{\mathrm{b}}$ & $9.13 \pm$ & 3.07 \\
\hline Antibody titer & $1.00 \pm 0.00^{\mathrm{b}}$ & $105.60 \pm 9$ & $93.02^{\mathrm{ab}}$ & $192.00 \pm 1$ & 10.85 \\
\hline
\end{tabular}

Note: $\mathrm{R} 0=$ ration without supplementation of BSF larva meal; $\mathrm{R} 1=$ ration supplemented with $6.57 \%$ BSF larva meal to substitute $50 \%$ fish meal; R2= ration supplemented with $13.15 \%$ BSF larva meal to substitute $100 \%$ fish meal; Means in the same row with different superscripts differ significantly $(\mathrm{p}<0.05)$.

titer of antibody against AI virus compared to control quails without BSF larvae meal supplementation (Table 6).

\section{Production Performances}

Table 7 presents the growth performances of quails fed ration supplemented with different levels of BSF larvae meal during the feeding trial. Feed consumption and feed conversion of experimental quails fed ration supplemented with BSF larvae meal at the levels of $0 \%$ (R0), $6.57 \%$ (R1), and $13.15 \%$ (R2) were similar. However, egg production and egg mass were significantly increased by the increased level of BSF larvae meal supplementation in the ration $(p<0.05)$. Quails fed ration supplemented with BSF larvae meal at the level of $13.15 \%$ had the highest egg production. However, quails fed ration supplemented with $13.15 \%$ BSF larvae meals had similar egg production compared to quails fed ration supplemented with BSF larvae meal at the level of $6.37 \%$. In addition, quails fed ration supplemented by BSF larvae meal at the level of $6.57 \%$ had similar egg production $(\mathrm{p}>0.05)$ compared to control quails without BSF larvae meal supplementation. Quails fed ration supplemented with BSF larvae meal at the level of $13.15 \%$ (R2) had the highest egg
Table 7. The average of feed consumption, egg production, egg mass, and feed conversion in quails fed ration with different levels of black soldier fly (BSF) larvae meal supplementation during 6 weeks of treatment

\begin{tabular}{lcccc}
\hline \multirow{2}{*}{ Variables } & \multicolumn{4}{c}{ Treatments } \\
\cline { 2 - 5 } & \multicolumn{2}{c}{ R0 } & R1 & R2 \\
\hline $\begin{array}{l}\text { Feed consumption } \\
\text { (g quail }^{-1} \text { day }^{-1} \text { ) }\end{array}$ & $19.10 \pm$ & 1.51 & $19.38 \pm 1.41$ & $19.85 \pm 1.14$ \\
Egg production $(\%)^{2}$ & $51.21 \pm 11.73^{\mathrm{b}}$ & $55.00 \pm 3.98^{\mathrm{ab}}$ & $62.38 \pm 2.60^{\mathrm{a}}$ \\
Egg mass (g quail $^{-1}$ ) & $449.18 \pm 110.23^{\mathrm{b}}$ & $503.96 \pm 49.71^{\mathrm{b}}$ & $610.76 \pm 30.37^{\mathrm{a}}$ \\
Feed conversion & $2.00 \pm$ & 0.13 & $1.87 \pm 0.11$ & $1.83 \pm 0.10$ \\
\hline
\end{tabular}

Note: $\mathrm{R} 0=$ ration without supplementation of BSF larva meal; R1= ration supplemented with $6.57 \%$ BSF larva meal to substitute $50 \%$ fish meal; R2 = ration supplemented with $13.15 \%$ BSF larva meal to substitute $100 \%$ fish meal; Means in the same row with different superscripts differ significantly $(p<0.05)$.

mass compared to quails fed ration supplemented with BSF larvae meal at the levels of $0 \%$ (R0) and 6.57\% (R1) $(\mathrm{p}<0.05)$. However, quails fed ration supplemented with BSF larvae meal at the level of $6.57 \%$ (R1) had similar egg mass compared to control quails without BSF larvae meal supplementation (R0).

\section{DISCUSSION}

\section{Hematological Profile}

The average erythrocyte number was lower than the standard of Campbell (2015). This smaller number of erythrocytes was affected by some factors such as age, sex, physiological status, activity, the nutritional content of the ration, and environmental condition (temperature and humidity) (Guyton \& Hall, 2010; Campbell, 2015). Also, avian species tend to be easier to have a decreasing erythrocyte number compared to mammals (Campbell, 2015). However, this condition is physiologically normal since the reduction is caused by the short life span of the erythrocyte, i.e., around 33-35 days for quails. For avian species, the short life span of erythrocyte may be related to the higher body temperature and metabolic rate compared to mammals (Scanes, 2014).

Furthermore, the average of hematocrit was at the range of the standard value of Campbell (2015). The 
quails in this study were comfortable enough to adapt to the environment; also, they get to drink very well. Hematocrit represents the number of red blood cells compared to the total whole blood which has close relation with body water. Hematocrit conditions can also be affected by some factors such as stress conditions, dehydration, and diseases (Guyton \& Hall, 2010).

The treatments showed no significant effect on hemoglobin percentage, and we found that the value was lower than the standard (Campbell, 2015). The hemoglobin presence is affected by oxygen concentration and the number of erythrocytes; therefore, the low concentration of erythrocyte is responsible for the decreased hemoglobin concentration (Weiss \& Wardrop, 2010). The humidity in the cage, especially in the morning, was very high (more than $85 \%$ relative humidity) and this condition could decrease oxygen concentration.

Mean corpuscular volume (MCV) indicates the average size of red blood cells. In this study, the treatments did not affect the MCV score. The score was found to be at the range of standard of Campbell (2015). Mean corpuscular hemoglobin concentration (MCHC) was also not affected by the treatments. The MCHC for control quails without supplementation of BSF larvae meal (R0) and quails fed ration supplemented with BSF larvae meal at the level of $6.57 \%$ (R1) were still in the standard values according to Campbell (2015). However, the value of MCHC for quails fed ration supplemented with BSF larvae meal at the level of $13.15 \%$ (R2) was lower than the standard. The MCHC represents the abundance of hemoglobin in the red blood cell. In this case, the low value of MCHC could be associated with iron deficiency, since iron is the main component of heme, the molecule responsible for hemoglobin formation (Blake, 2008).

All white blood cells, namely leukocytes, have nuclei and the ability to move independently and actively in response to the pathogen's attacks (Campbell, 2015). The high leukocyte count (leukocytosis) is commonly triggered by physiological processes such as infection or inflammation (Weiss \& Wardrop, 2010). In this study, even though the leukocyte count in quails without BSF larvae meal supplementation (R0) is higher compared to the other groups, the concentration is still in the range of standard level. Leukocytes play a role in response to immune challenges. The use of insect-like silkworm pupa powder can maintain the number of leukocytes in laying quails for functioning the immune system because the powder of silkworm pupae contains polysaccharides silk rose, which can boost the immune function (Anggraeni et al., 2011).

The $\mathrm{H} / \mathrm{L}$ ratio is one of the stress indicators in avian species. The higher $\mathrm{H} / \mathrm{L}$ ratio is associated with a highstress level. In tropical countries such as Indonesia, heat stress due to the high environmental temperature can be a primary contributor to the stress condition. When the ambient temperature increases, the secretion of glucocorticoid hormone into the blood also increases to maintain homeostasis (Davis et al., 2008). The increased glucocorticoid hormone secretion will induce the formation and release of young heterophils from the bone marrow, resulting in the higher heterophils concentration in the blood (Blencha, 2000). Moreover, the rising level of glucocorticoid hormone can also intervene in the function of interleukin (IL), a cytokine cell that plays an essential role as a messenger cell in the immune system The H/L ratio in this study ranged from 0.33 to 0.44 meaning that the experimental quails were not in a stress condition. The normal standard of $\mathrm{H} / \mathrm{L}$ ratio is $0.30-0.50$.

\section{Macrophage Phagocytic Activity and Capacity}

The effect of BSF larvae meal supplementation on immune response can be seen from the reaction of macrophage against the pathogen. In this study, phagocytic activity and capacity of peritoneum macrophage against the non-protein A of Staphyllococcus aureus were assessed.

Phagocytosis constitutes the engulfment of bacterial cells or other foreign particles entering the body by the immune cells (lymphoid cell) capable of performing phagocytic activities (Wibawan \& Soejoedono, 2013). Phagocytic cells are grouped into three types, i.e., granulocyte cell (heterophils, eosinophils, and basophils), macrophage, and dendritic cells (Devereux, 2002). The phagocytosis can be a terminal phase in the non-specific immune system. In this phase, protein and enzyme inside the granules exert leading roles to kill the pathogen (Wibawan \& Soejoedono, 2013).

The higher macrophage phagocytic activities in quails fed ration supplemented with BSF larvae meal at the levels of $6.57 \%$ (R1) and $13.15 \%$ (R2) means that there are more macrophage cells which actively response to fight the pathogen. Additionally, the higher macrophage phagocytic capacity means the higher the number of pathogens that can be destroyed by the macrophages. In our experiment, the macrophage phagocytic activities were increased significantly due to the presence of chitin in the BSF larva meal.

The abundance of chitin in insects is dependent on its life phase and physical characteristics. Based on some previous researches, the chitin content in BSF larva is around $0.27 \%-9.6 \%$ dry matter (Finke, 2007; Kroeckel et al., 2012; Bovera et al., 2016), while according to Diener et al. (2011) for prepupa (end of larval phase), the chitin content is $8.72 \%$ dry matter. In the present study, chitin contents in ration supplemented with BSF larvae meal at the levels of $6.57 \%$ (R1) and $13.15 \%$ (R2) could be estimated to reach approximately $0.57 \%$ and $1.15 \%$, respectively. The amino acids, such as arginine and histidine in BSF, are quite high (Table 1). Those amino acids are also related to the immune system in the body.

\section{Antibody Titer}

The result showed that the highest antibody titer found in quails fed ration supplemented with BSF larvae meal at the levels of $6.57 \%$ (R1) and $13.15 \%$ (R2) compared to control quail without BSF larvae meal supplementation (RO). This condition proves that some amino acids and peptides in BSF larvae meal can improve the body's immune systems of the experimental quails (Table 1). BSF larvae as an insect can be a source of animal protein in the future for poultry farming 
(Rumpold \& Schluter, 2013). Another potential value owned by insects is the discovery of various bioactive substances with beneficial characteristics (Hirose et al., 2013). Insects are not only useful as a source of animal protein in food production as well as feed, but they also provide benefits in the pharmacological and medical areas which can protect animals and livestock from various risks of many diseases. The antibody titer against the avian influenza virus measured using the Hemagglutination Inhibition test showed significantly higher values in quails fed ration supplemented with BSF larvae meal compared to the control group without supplementation of BSF larvae meal. In this study, vaccination was not performed; thus, it was assumed that the quails were exposed naturally to the same amount of AI virus. The specific immune system is linked with a response to a particular antigen through the antigenantibody reaction (Wibawan \& Soejoedono, 2013).

\section{Production Performances}

Based on the results, the BSF larvae meal in the diet did not affect the diet palatability. However, in spite of statistically insignificant difference, feed consumption of quails fed ration supplemented with BSF larvae meal at the level of $13.15 \%$ (R2) tended to be higher, being 0.47 $\mathrm{g}$ higher compared to quails fed ration supplemented with BSF larvae meal at the levels of $6.57 \%$ (R1) and 0.75 $\mathrm{g}$ higher compared to control quails without BSF larvae meal supplementation (R0).

Furthermore, feed consumption seemed to be in line with egg production and egg mass. Control quails without BSF larvae meal supplementation (R0) were found to show the lowest feed consumption, and in turn, also showed a lower egg production and egg mass compared to quails fed ration supplemented with BSF larvae meal at the levels of $6.53 \%$ (R1) and $13.15 \%$ (R2). The highest fat concentration in the diet supplemented with BSF larvae meal at the level of $13.15 \%$ (R2) caused the high fat intake in the quails fed this ration, which related to the highest egg production. Fat, especially cholesterol, is a precursor of steroid hormones that induce egg production. The low feed consumption means that the nutrient intake is also low. According to Widjastuti et al. (2014), the low feed consumption and energy consumption during the laying period will cause a decrease in egg production and egg mass.

In this study, the feed conversion for quails fed ration supplemented with BSF larvae meal at the level of $13.15 \%$ (R2) was more efficient. The quails consumed less feed but could produce more eggs. Feed conversion is highly related to feed consumption and the ability of the animal to convert the diet into meat or eggs. The lower feed conversion can indicate that the animals can more efficiently convert the feed into the desired output. Additionally, low feed conversion was also meaningful to the production cost. Leeson \& Summer (2005) reported factors affecting feed conversion, i.e., nutrients content of the diet, egg production, egg weight, and environmental condition (temperature and humidity).

\section{CONCLUSION}

The black soldier fly (BSF) larvae meal can be used as an alternative substitution to fish meal up to $13.15 \%$ in quail ration, based on the improvement of immune response and the increase in egg production.

\section{CONFLICT OF INTEREST}

We certify that there is no conflict of interest with any financial, personal, or other relationships with other people or organizations related to the material discussed in the manuscript.

\section{REFERENCES}

Anggraeni, N., A. Farajallah, \& D. A. Astuti. 2016. Blood profile of quails (Coturnix coturnix japonica) fed ration containing silkworm pupae (Bombyx mori) Powder extract. Med. Pet. 39:1-8. https://doi.org/10.5398/medpet.2016.39.1.1

OIE (World Organization for Animal Health). 2015. Manual of Diagnostic Tests and Vaccines for Terrestrial Animals. http://www.oie.int/ [4 June 2017].

Blake, S. 2008. Vitamins and Minerals Demystifed. The McGraw-Hill Companies, Inc, New York.

Blencha, F. 2000. Immune System Response to Stress. In: G. P. Moberg \& J. A. Mench (Eds). The Biology of Animal Stress: Basic Principles and Implications for Animal Welfare. CAB Int, New York. p. 111-122. https://doi. org/10.1079/9780851993591.0111

Bovera, F., R. Loponte, S. Marono, G. Piccolo, G. Parisi, V. Iaconisi, L. Gasco, \& A. Nizza. 2016. Use of Tenebrio molitor larvae meal as protein source in broiler diet: Effect on growth performance, nutrient digestibility, and carcass and meat traits. J. Anim. Sci. 94:639-647. https://doi. org/10.2527/jas.2015-9201

Campbell, T.W. 2015. Exotic Animal Hematology and Cytology. 4th ed. John Wiley \& Sons, Inc, Oxford. https:// doi.org/10.1002/9781118993705

Choi, W. H., J. H. Yun, J. P. Chu, \& K. B. Chu. 2012. Antibacterial effect of extracts of Hermetia illucens (Diptera: Stratiomyidae) larvae against Gramnegative bacteria. Ento. Res. 42: 219-226. https://doi. org/10.1111/j.1748-5967.2012.00465.x

Davis, A., D. Maney, \& J. Maerz. 2008. The use of leukocyte profiles to measure stress in vertebrates: a review for ecologists. Functional. Eco. 22:760-772. https://doi. org/10.1111/j.1365-2435.2008.01467.x

Devereux, G. 2002. The Immune System: An Overview. In: P. C. Calder, C. J. Field, \& H. S Gill (Eds). Nutrition and immune function. CABI Pub, Oxon. p. 1-20. https://doi. org/10.1079/9780851995830.0001

Diener, S., N. M. Studt Solano, F. Roa Gutiérrez, C. Zurbrügg, \& K. Tockner. 2011. Biological treatment of municipal organic waste using black soldier fly larvae. Waste. Biomass. Valor. 2:357-363. https://doi.org/10.1007/s12649-011-9079-1

Diener, S., C. Zurbrügg, \& K. Tockner. 2009. Conversion of organic material by BSF larvae-Establishing optimal feeding rates. Waste. Manag. Res.. 27: 603-610. https://doi. org $/ 10.1177 / 0734242 X 09103838$

Finke, M.D. 2007. Estimate of chitin in raw whole insects. Zoo Biol. 26:105-115. https://doi.org/10.1002/zoo.20123

Guyton, A.C., \& J. E. Hall. 2010. Textbook of Medical Physiology. 8th ed. Elsevier Inc, Mississippi.

Hirose, Y., E. Ohta, Y. Kawai, \& S. Ohta. 2013. Dorsamin-A's, glycerolipids carrying a Dehydrophenylalanine Ester Moiety from the seed-eating larvae of the Bruchid Beetle 
Bruchidius dorsalis. J. Nat. Prod. 76:554-558. https://doi. org/10.1021/np300713c

Jayanegara A, B. Novandri, N. Yantina, \& M. Ridla. 2017. Use of black soldier fly larvae (Hermetia illucens) to substitute soybean meal in ruminant diet: An in vitro rumen fermentation study. PubMed. 10:1439-1446. https://doi. org/10.14202/vetworld.2017.1439-1446

Kim, S.A. \& M. S. Rhee. 2016. Highly enhanced bactericidal effects of medium chain fatty acids (caprylic, capric, and lauric acid) combined with edible plant essential oils (carvacrol, eugenol, b-resorcylic acid, trans-cinnamaldehyde, thymol, and vanillin) against Escherichia coli O157:H7. Food. Control. 60: 447-454. https://doi.org/10.1016/j. foodcont.2015.08.022

Kroeckel, S., A. G. E. Harjes, I. Roth, H. Katz, S. Wuertz, A. Susenbeth, \& C. Schulz. 2012. When a turbot catches a fly: evaluation of a prepupae meal of Black soldier fly (Hermetia illucens) as fish meal substitute - growth performance and chitin degradation in juvenile turbot (Psetta mazima). Aquaculture. 364/365:345-352. https://doi. org/10.1016/j.aquaculture.2012.08.041

Leeson, S. \& J. D. Summers. 2005. Commercial Poultry Nutrion. 3th ed. Nottingham University Pr, Canada.

Makkar, H. P. S., G. Tran, V. Heuzé, \& P. Ankers. 2014. State of the art on use of insects in animal feed. Anim. Feed. Sci. Technol. 197:1-33. https://doi.org/10.1016/j. anifeedsci.2014.07.008

Martínez-Sánchez, A., C. Magaña, M. Saloña, \& S. Rojo. 2011. First record of Hermetia illucens (Diptera: Stratiomyidae) on human corpses in Iberian Peninsula. For. Sci. Int. 206: 76-78. https://doi.org/10.1016/j.forsciint.2010.10.021

Maurer, V., M. Holinger, Z. Amsler, B. Früh, J. Wohlfahrt, A. Stamer, \& F. Leiber. 2015. Replacement of soybean cake by Hermetia illucens meal in diets for layers. Journal of Insects as Food and Feed 2: 83-90. https://doi.org/10.3920/ JIFF2015.0071
Myers, N., R. A. Mittermeier, C. G. Mittermeier, G. A. B. da Fonseca, \& J. Kent. 2000. Biodiversity hotspots for conservation priorities. Nature. 403: 853-858. https://doi. org $/ 10.1038 / 35002501$

Oliveira, F., K. Doelle, L. Richard, \& J. R. O'Reilly. 2015. Assessment of Diptera: Stratiomyidae, genus Hermetia illucens (L.,1758) using electron microscopy. JEZS. 3:147-152.

Park, H.H. 2016. Black Soldier Fly Larvae Manual. UMass Amherst, Massachusetts.

Park, S.I., B. S. Chang, \& S. M. Yoe. 2014. Detection of antimicrobial substances from larvae of the black soldier fly, Hermetia illucens (Diptera: Stratiomyidae). Ento. Res. 44: 58-64. https://doi.org/10.1111/1748-5967.12050

Rumpold, B. A. \& O. K. Schluter. 2013. Nutritional composition and safety aspects of edible insects. Mol. Nutr. Food Res. 57:802-23. https://doi.org/10.1002/mnfr.201200735

Scanes, C. G. 2014. Organ System Theme: Blood. C. G. Scanes (Eds). Sturkie's Avian Physiology. 6th ed. Academic Pr, Heidelberg. p. 167-190.

Steiner, T. \& B. Syed. 2015. Phytogenic Feed Additives in Animal Nutrition. Á. Máthé (Eds). Medicinal and Aromatic Plants of the World. pp. 403-423. https://doi. org/10.1007/978-94-017-9810-5_20

van Huis, A., J. van Itterbeeck, H. Klunder, E. Mertens, A. Halloran, G. Muir, \& P. Vantome. 2013. Edible Insects - Future Prospects for Food and Feed Security. FAO Forestry, Rome.

Wibawan, I. W. T. \& R. D. Soejoedono. 2013. Intisari Imunologi Medis. Fakultas Kedokteran Hewan IPB, Bogor.

Widjastuti, T., R. Wiradimadja, \& D. Rusmana. 2014. The effect of substitution of fish meal by Black soldier fly $(\mathrm{H}$. illucens) maggot meal in the diet on production performance of quail. Anim. Sci. 57:125-129.

Weiss, D.J. \& K. J. Wardrop. 2010. Schalm's Veterinary Hematology. 6th ed. Blackwell Pub Ltd., Iowa. 